\title{
PANDANGAN WARTAWAN TELEVISI MENGENAI PELIPUTAN KERUSUHAN AKSI 22 Mei 2019
}

\author{
${ }^{1}$ Lisna Nurpadillah, ${ }^{2}$ Ujang Saepullah, ${ }^{3}$ Khoiruddin Muchtar \\ UIN Sunan Gunung Djati Bandung123 \\ email: nurpadillahlisna@gmail.com ${ }^{1}$, ujang.saefullah@uinsgd.ac.id ${ }^{2}$, \\ khoiruddin@uinsgd.ac.id ${ }^{3}$
}

\begin{abstract}
Abstrak
Penelitian ini bertujuan untuk mengetahui pemahaman, pemaknaan serta pengalaman wartawan televisi pada saat peliputan kerusuhan Aksi 22 Mei 2019. Penelitian ini menggunakan paradigma konstruktifis dan pendekatan kualitatif, serta menggunakan teori fenomenologi dari Alfred Schutz. Informan Penelitian ini menggunakan informan wartawan dari beberapa televise swasta yaitu; wartawan News TV, Net TV, Kompas TV, RTV, Jawa Pos TV, TVOne dan CNN Indonesia. Sumber data berkaitan dengan data yang dibutuhkan oleh peneliti yaitu pengalaman wartawan televisi tentang peliputan kerusuhan Aksi 22 Mei 2019. Hasil penelitian menunjukan,bahwa wartawan televisi memahami peliputan kerusuhan Aksi 22 Mei 2019 yaitu definisi peliputan kerusuhan Aksi 22 Mei 2019, etika peliputan kerusuhan dan posisi peliputan wartawan. Wartawan televisi juga memaknai peliputan kerusuhan Aksi 22 Mei 2019 yaitu pentingnya peran wartawan televisi dan mendahulukan humanisme. Berdasarkan pengalamannya
\end{abstract}

Kata Kunci: Wartawan, Peliputan, Kerusuhan

\begin{abstract}
This study aims to determine the understanding, interpretation, and experience of television journalists at the time of covering the riots of May 22,2019, Action. This study uses a constructive paradigm and a qualitative approach and uses the phenomenological theory of Alfred Schutz. In-formant This research uses journalist informants from several private televise namely; News TV reporters, Net TV, Kompas TV, RTV, Jawa Pos TV, TVOne, and CNN Indonesia. Data sources relate to the data needed by researchers, namely the experience of television reporters about the riot-ing of the May 22, 2019 action. The results showed that television journalists under-stood the coverage of the riots of May 22, 2019, namely the definition of covering the riots of May 22, 2019, the ethics of covering riots, and the reporter's reporting posi-tion. Television reporters also interpret the coverage of the May 22, 2019, action riots, namely the importance of the role of television journalists and prioritizing hu-manism. Based on his experience
\end{abstract}

Key Words: Reporter, Coverage, Unrest

\section{PENDAHULUAN}

Jurnalistik televisi merupakan perkembangannya salah satu produk jurnalistik. Jurnalistik terlevisi adalah kegiatan mencari, mengumpulkan, mengolah, dan menyebarluaskan berita melalui media televisi. Dalam proses peliputan jurnalistik televisi terdapat dua orang yang melakukannya yaitu reporter dan kameramen. Sesuai dengan tugasnya, jurnalis televisi harus menguasai lapangan untuk mencari 
data yang akan dikemas menjadi berita dan disampaikan kepada khalayak. Biasanya jurnalis televisi melakukan live report atau laporan langsung di lokasi kejadian seperti meliput bencana, kriminal, kerusuhan, dan sebagainya.

Kerusuhan terjadi jika ada dua kelompok berkumpul di suatu tempat yang sama untuk melakukan tindakan kekerasan, hal ini karena sebagai upaya tindakan balasan terhadap perlakuan yang dirasa tidak adanya keadilan atau suatu tindakan penentangan terhadap sesuatu. Biasanya terjadinya kerusuhan disebabkan terjadinya kondisi hidup masyarakat yang tidak baik, adanya tindakan penindasan yang dilakukan pemerintah kepada rakyat, perselisihan agama atau etnis, serta tidak menerima hasil pertandingan olahraga. Kerusuhan atau konflik bisa terjadi pada manusia dengan beragam penyebab.

Indoenesia mencatatkan sejarah lagi mengenai peristiwa kerusuhan. Berawal pada 21 Mei 2019, sebagian masyarakat Indonesia menyelenggarakan Aksi 21 Mei untuk menyampaikan aspirasi atau pendapat terkait hasil rekapitulasi Pemilu 2019 di depan kantor Bawaslu Republik Indonesia. Aksi tersebut berjalan dengan damai, bahkan para peserta unjuk rasa dan pihak aparat berbaur. Massa aksi damai mengadakan doa bersama, buka puasa bersama dan sholat tarawih berjamaah tepat di depan kantor Bawaslu. Hingga pada akhirnya aksi itu pun selesai sekitar pukul 21.00 WIB.

Tetapi, menjelang tengah malam terjadi kerusuhan yang dilakukan oleh kelompok lain kepada Brimob. Kerusuhan tersebut membuat para wartawan tidak mau kehilangan data kejadian tersebut untuk diberitakan kepada khalayak. Pada kerusuhan ini terjadinya kekerasan terhadap wartawan.

Jurnalis yang menjadi korban tindakan kekerasan ketika meliput aksi unjuk rasa berdampak kerusuhan pada 21-22 Mei 2019, semakin bertambah. Catatan semen-tara Aliansi Jurnalis Independen (AJI) Jakarta membuktikan ada 20 jurnalis di berbagai media yang menjadi korban kerusuhan. Kasus kekerasan tersebut terjadi di berbagai tempat di Jakarta, seperti halnya di kawasan Thamrin, Pertamburan, dan Slipi Jaya. Diduga kuat pelaku kekerasan terhadap para jurnalis dilakukan oleh pihak kepolisian dan massa yang melakukan. Kasus kali ini merupakan kasus kekerasan terburuk yang dilakukan terhadap para wartawan sejak reformasi. AJI Jakarta dan LBH Pers mengecam keras terhadap aksi kekerasan dan upaya penghalangan kerja jurnalis yang dilakukan oleh aparat kepolisian maupun massa yang melakukan aksi. Intimidasi dan kekerasan terhadap jurnalis saat meliput peristiwa kerusuhan, bisa dikategorikan sebagai senseor terhadap produk jurnalistik. Perbuatan tersebut merupakan pelanggaran pidana sesuai dengan pasal 18 undang-undang Nomor 40 Tahun 1999 Tentang Pers, yang menyatakan bahwa, Setiap orang yang menghalangi kebebasan pers diancam penjara maksimal dua tahun dan denda maksimal 500 juta (Mardira, 2019).

Menurut catatan Aliansi Jurnalis Indonesia (AJI) terdapat 20 wartawan yang bertugas dalam peristiwa tersebut dan menerima kekerasan langsung meupun tidak langsung, misalnya melalui media sosial. Tindakan kekerasan yang menimpa wartawan berupa persekusi, intimidasi, pemukulan, ancaman, perampasan alat 
peliputan. Menghalangi kegiatan peliputan, penghapusan foto dan video, pelemparan batu serta pembakaran motor milik wartawan.

Dalam berita konflik, televisi merupakan media yang sangat di percaya. Karena televise menyajikan audio dan visual untuk menjadi bukti yang tidak bisa terbantahkan. Televisi merupakan media yang sangat cepat untuk menyebarluaskan berita kepada khalayak luas. (Morissan, 2009: 209).

Wartawan sebagai orang yang berada di lokasi kerusuhan memiliki jiwa kemanusiaan yang wajar pada suatu kenyataan yang dialami. Ketika melakukan peliputan wartawan tidak luput dari risiko yang akan dihadapinya. Sebagai pencari berita, wartawan memposisikan diri sebagai orang pertama yang melihat dan merasakan peristiwa tersebut. Wartawan akan dihadapkan dengan orang-orang yang menjadi korban peristiwa tersebut.

Wartawan yang melakukan peliputan kerusuhan atau konflik sering dihadapkan dengan kondisi pengambilan tindakan antara profesionalisme atau humanisme. Sebagai pencari berita yang bertugas di lokasi kerusuhan, wartawan dituntut untuk mendapatkan data dari berbagai sumber seperti pihak aparat, massa aksi maupun korban kerusuhan. Tetapi hal itu tidak mudah untuk dilakukan, dalam kondisi yang penuh emosional wartawan tidak mungkin melakukan wawancara terhadap korban. Sesama manusia, wartawan juga membuka dinding humanisme ketika dihadapkan adanya korban kerusuhan baik dari masyarakat maupun rekan wartawan. Selain memiliki jiwa kemanusiaan wartawan juga memiliki jiwa profesionalisme untuk menyebarkan berita sesuai kenyataan yang terjadi di lokasi kerusuhan. Wartawan berada di posisi netral, tidak berpihak pada kelompok manapun. Berita yang disampaikan wartawan televisi tidak dapat terbantahkan karena menyajikan berita secara live report. Reporter yang melaporkan kondisi lapangan didukung dengan video yang apa adanya dan tidak dapat terbantahkan.

Berdasarkan uraian di atas, kerusuhan Aksi 22 Mei 2019 merupakan liputan yang sangat memilukan dan mengancam wartawan. Disini peneliti merasa tertarik meneliti pemahaman, pemaknaan dan pengalaman wartawan televisi pada saat peliputan peristiwa kerusuhan Aksi 22 Mei 2019 sebagai fokus penelitian. Dalam penelitian ini peneliti menggunakan studi fenomenologi kerena metode ini di pandang tepat dan relevan dalam menggali pengalaman sadar wartawan televisi pada saat peliputan kerusuhan Aksi 22 Mei 2019.

Beberapa penelitian terdahulu yang sejenis telah banyak dlakukan diantaranya adalah tentang jurnalisme sensitif bencana dalam manajemen pencarian, pengelolaan, informasi dan pemberitahuan bencana di ruang redaksi. Penelitian ini menjelaskan bahwa, pentingnya seorang wartawan untuk memiliki kemampuan dalam mendapatkan akurasi dan verifikasi data dalam kegiatan liputan bencana dan sekaligus memberikan harapan kepada warga yang terdampak bencana (Sukmono, Filosa Gita \& Junaedi, 2018).

Kedua, mengenai pemberitaan harian Waspada mengenai pembakaran Gereja di Aceh Singkil yang telah menerapkan empat kategori jurnalisme damai versi Johan Galtung dan memenuhi semua indicator dalam setiap kategorinya (Nusyur, 2017). Ketiga, tentang persepsi wartawan terhadap aktivitas jurnalistik investigasi. Para wartawan memahami secara normaif dan praktis tentang jurnalistik dan aktifitasnya (Dirgahayu, 2018). 
Keempat, mengenai Propesionalitas Wartawan Televisi Lokal Di Batu TV. Hasil penelitian menunjukan bahwa jurnalis di batu TV tidak menjadi pribadi "bebas" yang memproduksi kebenaran melalui hasil jurnalistik, namun lebih karena tuntutan kapitalisme korporasi (Wibowo, 2018). Kelima, tentang Studi Profesionalisme Melalui Pengalaman Komunikasi Jurnalis Perempuan Di Media Massa Kota Ambon (Sulaeman, 2015).

Beberapa penelitian yang sudah dijelaskan tersebut, lebih banyak menekankan pada aspek normative wartawan dalam melakukan kegiatan jurnalistik, dengan tidak meninggalkan profesionalitas sebagai seorang wartawan. Sedangkan peneliti lebih menekankan pada aspek pemahaman, pemaknaan serta pengalaman wartawan televisi pada saat peliputan kerusuhan Aksi 22 Mei 2019

Penelitian ini bertujuan untuk memperoleh gambaran pemahaman wartawan televisi mengenai peliputan kerusuhan Aksi 22 Mei 2019, pemaknaan wartawan televisi mengenai peliputan kerusuhan Aksi 22 Mei 2019, dan pengalaman wartawan televisi pada saat peliputan kerusuhan Aksi 22 Mei 2019. Lokasi penelitian di laksanakan di Kota Jakarta. Penelitian ini membutuhkan 7 wartawan televisi yang meliput kerusuhan Aksi 22 Mei 2019 di Jakarta. Peneliti memilih Wartawan Net TV, Inews TV, CNN Indoensia, RTV, Kompas TV, TVOne, dan JawaPos TV. Metode yang digunakan dalam penelitian ini adalah studi fenomenologi karena fokus pada penelitian ini untuk mengetahui dunia dari sudut pandang wartawan televisi yang mengalami peliputan kerusuhan Aksi 22 Mei 2019, Dengan demikian, penelitian fenomenologi harus menunda proses penyimpulan mengenai sebuah fenomena. Jadi, mempertanyakan dan meneliti terlebih dulu fenomena yang tampak, dengan mempertimbangkan aspek kesadaran yang ada padanya (Kuswarno, 2009: 35-36).

\section{KERANGKA TEORI}

Penelitian ini merujuk kepada beberapa konsep yang dimulai dari wartarwan televisi, kerusuhan dan bagaimana fenomena ketika peliputan kerusuhan Aksi 22 Mei 2019. Televisi yaitu media yang memiliki sifat audio visual dengan menyajikan suatu berita yang mengarah pada informasi yang sesuai dengan kenyataan. Kekuatan media televisi yaitu suara dan gambar, dibandingkan dengan media lainnya, televisi lebih menarik bagi masyarakat. Pengaruh berita yang disajikan media televisi memiliki sifat power full, sebab adanya aspek suara dan gambar sehingga dapat memberikan dampak yang kuat kepada khalayak luas. Kelebihan media televisi lainnya yaitu sifatnya yang audio-visual dapat didengar dan dilihat secara langsung, di samping khalayak mendapatkan informasi atau berita yang nyata, yang sesuai dengan keadaan yang sebenarnya terjadi. Televisi dipengaruhi beberapa faktor, yaitu khalayak atau pemirsa, alokasi waktu, durasi tayangan, dan cara menyajikan berita.

Televisi adalah gabungan dari media adio dan visual, bisa bersifat pendidikan, hiburan ataupun informative, bias juga merupakan gabungan dari ketiganya. Televisi juga telah menjadi lingkungan simbolik bagi masyarakat dan merupakan sistem bercerita yang tersentralisasi (Syahputra, 2013: 41).

Televisi merupakan media yang paling mudah untuk dinikmati semua kalangan dari berbagai latar belakang usia dan pendidikan. Dari beberapa media massa seperti surat kabar, majalah, radio, maka televise adalah media 
yang paling banyak diminati oleh masyarakat, karena memudahkan khalayak untuk mendapatkan informasi dengan mudah (Muchtar \& Ghalia, 2018: 149).

Tugas wartawan menyebarluaskan informasi merupakan suatu kebaikan untuk tujuan kebaikan, dalam agama islam disebut dakwah bil qalam (Purnama, 2019: 39). Peliputan berita merupakan suatu kegiatan mengumpulkan data yang ada di lapangan dan diolah menjadi sebuah berita yang dilakukan oleh wartawan. Dalam peliputannya wartawan melakukan perekaman berupa suara dan gambar menggunakan tape recorder dan kamera. Berita televisi dilakukan secara live report atau laporan langsung dengan menggunakan kamera video yang dilakukan oleh reporter dan kameramen.

Jadi wartawan televisi adalah orang yang mencari, mengumpulkan, mengolah dan menyebarluaskan berita kepada khalayak melalui televisi. Wartawan televisi dibagi menjadi dua yaitu reporter dan kameramen. Reporter bertugas melaporkan secara live dihadapan kamera sedangkan kameramen adalah orang yang mengendalikan kamera untuk liputan berlangsung.

Sedangkan Peliputan Berita menurut Kamus Besar Bahasa Indonsia peliputan adalah proses pengumpulan data dan informasi dilapangan yang dilakukan wartawan atau jurnalis (KBBI, 2016). Berita merupakan laporan yang tercepet baik itu suatu kejadian nyata atau ide terhangat, yang penting dan menarik. Berita juga harus mencakup syarat-syarat berita. Berita tersebut disebarluaskan kepada khalayak luas melalui perantara media komunikasi massa (Darsono \& Muhaemin, 2012: 20).

Kerusuhan dalam peristiwa 22 Mei 2029 ini ditandai dengan adanya dua kelompok yang berkumpul di suatu tempat yang sama untuk melakukan tindakan kekerasan, sebagai upaya tindakan balasan terhadap perlakuan yang dirasa tidak adanya keadilan atau suatu tindakan penentangan terhadap sesuatu. Biasanya terjadinya kerusuhan disebabkan terjadinya kondisi hidup masyarakat yang tidak baik, adanya tindakan penindasan yang dilakukan pemerintah kepada rakyat, perselisihan agama atau etnis, serta tidak menerima hasil pertandingan olahraga. Kerusuhan atau konflik bisa terjadi pada manusia dengan beragam penyebab. Termasuk diantaranya adalah karena adanya media social yang menyebarkan berbagai informasi secara cepat, sejak munculnya media social sebagai media baru, banyak orang ikut ambil bagian dalam berbagai kegiatan dan aksi social (Shasrini et al., 2018).

Sedangkan penyebab yang menjadi pemantik adanya kerusuhan Aksi 22 Mei 2019 adalah adanya oknum massa yang menyerang aparat setelah bubarnya acara aksi damai. Aksi damai yakni aksi di mana massa menyuarakan pendapat mengenai hasil rekapitulasi pemilu 2019. Pada aksi yang dilaksakan pada 21 Mei berjalan lancar,kondusif, kooperatif, dan damai. tetapi pada malam hari tepat pukul 22.00 oknum massa yang bukan massa aksi damai menyerang aparat yang bermunculan dari berbagai titik di jakarta. Kerusuhan terjadi hingga tanggal 22 Mei 2019 dan oknum massa atau perusuh sangat brutal mereka melemparkan batu dan menyalakan petasan. Perusuh juga menyerang asrama Brimob dengan melemparkan abtu dan bom molotov serta merusak beberapa mobil brimob. 


\section{METODE PENELITIAN}

Penelitian tentang Motif Berinteraksi Imigran Ilegal dengan Masyarakat Kota Pekanbaru ini menggunakan paradigma Interpretif/ Konstruktivis karena peneliti ingin melihat dari sudut pandangan imigran ilegal sebagai subjek yang diteliti tentang bagaimana motif berinteraksi yang dilakukan oleh imigran ilegal dengan masyarakat Pekanbaru. Dalam peneliltian ini, penulis menggunakan metode kualitatif dengan pendekatan Fenomenologi. Pendekatan Fenomenologi memiliki tujuan untuk mengetahui sebuah fenomena dari sudut pandang individu yang mengalaminya secara langsung atau berkaitan dengan sifat-sifat alami manusia, dan makna yang ditempelkan kepadanya. Peneliti berpikir metode ini sangat tepat menjadi cara yang dapat menguraikan permasalahan pada penelitian Motif berinteraksi imigran illegal asal Afganistan dengan Masyarakat Kota Pekanbaru. Titchen dan Hobson dalam (Barnawi \& Darojat, 2018) menjelesakan fenomenologi sebagai sebuh ilmu tentang kehidupan manusia yang menjalani kesehariannya dalam konteks sosial tempat fenomena tersebut terjadii berdasarkan perpsektif individu yang terlibat langsung dalam sebuah pengalaman tersebut. Fenomena dapat diteliti melalui eksplorasi pengetahuan akses kesadarannya dan secara tidak langsung melalui investigasi terhadap individu yang langsung terlibat lewat pandangan serta pengaaman yang memiliki latar belakang makna yang sama. (Barnawi \& Darojat, 2018).

Teknik pemilihan informan adalah Teknik purposive, yaitu imigran illegal yangberada di rumah detensi imigrasi Kota Pekanbaru yang sudah menetap di selama satu tahun atau lebih serta telah bisa berbahasa Indonesia baik secara aktif maupun pasif. Penulis melakukan wawancara mendalam terhadap 11 orang imgran ilegal dari berbagai negara yang menghubi Rudenim Kota Pekanbaru. 11 orang tersebut sudah memenuhi kriteria yang telah penulis jelaskan diatas. Selain itu juga, penulis juga melakukan wawancara kepada pimpinan dan petugas Rudenim serta kepada masyarakat sekitar dimana para imgran ilegal tersebut beaktivitas dan berinteraksi satu sama lainnya. Sedangkan teknikpengumpulan data yang penulis gunakan dalam penelitian ini adalah dengan wawancara mendalam, observasi, serta dokumetasi.

\section{METODE}

Penelitian ini menggunakan kajian Fenomenologi. Kajian ini membangun penjelasan dan analisis psikologi, untuk menjelaskan dan menganalisis tipologi aktivitas mental subjektif. Teori tentang makna menjelaskan dan menganalisis isi objektif dari kesadaran seperti ide, konsep dan gambaran. Makna ideal dari beragam tipe sebagai isi yang disengaja, atau makna noematik dari bermacam-macam pengalaman. Isi tersebut dapat terdiri dari tindakan sadar yang berbeda-beda secara objektif dan bermanka ideal (Husserl dalam Kuswarno, 2009: 6)

Metode yang digunakan dalam penelitian ini adalah studi fenomenologi karena fokus pada penelitian ini untuk mengetahui dunia dari sudut pandang wartawan televisi yang mengalami peliputan kerusuhan Aksi 22 Mei 2019. Secara langsung atau berhubungan dengan sifat-sifat alami pengalaman manusia, dan makna yang melekat. Penelitian fenomenologi menunda proses penyimpulan terkait dengan sebuah fenomena. Jadi, meneliti terlebih dulu fenomena yang tampak dengan mempertimbangkan aspek kesadaran (Kuswarno, 2009: 35-36). 
Penelitian ini menggunakan jenis data primer dan sekunder. Jenis data primer penelitian adalah sasaran utama dari penelitian ini yaitu wartawan televisi yang meliput kerusuhan Aksi 22 Mei 2019. Sedangkan data sekundernya adalah studi dokumentasi dari buku maupun internet mengenai Aksi 22 Mei 2019. Data ini menjadi pendukung penelitian ini.

Dalam penelitian ini sumber data primer adalah wartawan televisi yang meliput peristiwa kerusuhan Aksi 22 Mei 2019. Wartawan yang menjadi informan sebanyak 3 orang. Data sekunder menjadi sumber referensi penelitian ini sebagai data pelengkap. Data untuk studi dokumentasi dari buku, sumber yang terkait adalah mengenai kerusuhan Aksi 22 Mei 2019.

Informan dalam penelitian yang akan dilakukan penulis adalah 7 Wartawan yang melaksanakan tugas kejurnalistikan dan termasuk kedalam wartawan televisi, baik reporter maupun kameramen. Informan yang dipilih adalah wartawan yang pernah melakukan peliputan peristiwa kerusuhan.

Jumlah informan yang diteliti dalam penelitian ini merujuk pada pendapat Dukes dalam buku Creswell (1998:122) yang berjudul "Qualitative Inquiry and Research Design: Choosing Among Five Traditions" yang menyatakan bahwa informan berjumlah 3 sampai 10 informan. Peneliti mewawancarai 7 watawan televisi yang meliput kerusuhan Aksi 22 Mei 2019 artinya sudah sesuai dengan yang dikatakan Dukes. Faktor terpenting dalam memilih informan yaitu diharapkan dapat menjelaskan pandangan wartawan mengenai pengalaman meliput peristiwa kerusuhan Aksi 22 Mei 2019.

Teknik pengumpulan data dilakukan dengan wawancara dan dokumentasi. Sedangkan teknik analisis data mengacu kepada Creswell, yaitu : Peneliti mendeskripsikan pengalamannya mengenai penelitian yang akan dibuat. Peneliti membuat latar belakang sebagai alasan adanya penelitian ini.

Peneliti menerima pernyataan dari informan mengenai cara informan memahami topik, pernyataan informan dirincikan oleh peneliti dan setipa pertanyaan memiliki nilai yang sama, serta rincian pernyataan dikembangkan peneliti dengan tindak adanya pengulangan atau tumpang tindih. Pernyataan informan dikelompokkan ke dalam unit-unit yang bermakna, peneliti merinci unitunit tersebut serta menuliskan penjelasan teks mengenai pengalamannya termasuk contoh.

Kemudian peneltii merefleksikan pemikirannya dengan menggunakan variasi imajinatif atau deskripsi structural, mencari makna keseluruhan yang memungkinkan dan melalui perspektif yang divergen, mempertimbangkan kerangka rujukan atas fenomena dan mengkonstruksikan gejala yang dialami (Ceswell dalam Kuswarno, 2009: 72).

\section{PEMBAHASAN}

Televise nasional seperti halnya Net TV, Inews TV, CNN Indoensia, RTV, Kompas TV, TVOne, dan JawaPos TV. INews TV merupakan televisi yang lebih berorientasi pada berita, berikut adalah visi Televisi yang diemban oleh beberapa TV swasta, diantaranya adalah Inews TV yaitu, menjadi televises nasional konsep local berjaringan yang menayangkan berbagai informasi dan inspirasi. Media Net Tv 
memiliki visi untuk membangun sebuah media yang menarik dan memberi kontribusi bermanfaat bagi kehidupan masyarakat Indonesia.

Kompas TV memiliki visi yaitu menjadi media yang paling kreatif di tingkat Asia Tenggara, mencerahkan kehidupan masyarakat, menayangkan programprgoram dan jasa edukatif, informatif, dan menghibur. Televisi Rajawali TV memiliki visi, dengan semangat inovasi, ingin berbagi nilai positif melalui produksi hiburan dan informasi akurat dengan maksud untuk membangun masyarakat Indonesia yang maju. Jawa Pos Tv memiliki visi yaitu lahir dari gagasan inovatif untuk menjadi lembaga penyiaran swasta Jawa Timur yang berbasis lokal. Berkontribusi mencerdaskan kehidupan bangsa. TV One memiliki visi yaitu untuk memajukan bangsa dan Media Televisi CNN Indonesia memiliki visi yaitu semua bisa saling berdiri sendiri bercerita sekaligus saling melengkapi sebagai sebuah kesatuan, mengungkapkan fakta secara apa adanya, menyampaikan sebuah peristiwa, perkara, yang layak untuk disampaikan, menarik, dan sebisa mungkin membuka wawasan.

Pemahaman Wartawan Televisi Mengenai Peliputan Kerusuhan Aksi 22

Mei 2019. Peliputan kerusuhan Aksi 22 Mei 2019 merupakan peliputan dimana terjadinya suatu kondisi yang dimainkan oleh provokator dari pihak masyarakat. Provokator tersebut membuat suatu kerusuhan. Hal itu terjadi ketika adanya aksi 21 yang mengedepankan perdamaian untuk mengemukakan pendapat kepada Bawaslu mengenai keputusan rekapitulasi pemilu dan saat massa aksi damai membubarkan diri terjadilah kerusuhan dari massa yang lain (Wawancara dengan Nadia Raissa pada 22 Juni 2019)

Kerusuhan Aksi 22 Mei 2019 merupakan adanya konflik antara rakyat vs aparat tetapi rakyat disini adalah oknum. Ketika kerusuhan terjadi pun massa aksi damai seperti FPI membantu aparat untuk melerai kerusuhan. Sebagai wartawan ketika meliput kerusuhan tidak boleh berpihak kepada satu kubu karena jika itu terjadi akan meimbulkan konflik yang semakin besar (Wawancara dengan Anan Suryana pada 26 Juni 2019)

Peliputan kerusuhan Aksi 22 Mei 2019 merupakan peliputan dimana adanya perusuh atau pihak demonstrasi yang melakukan kontak fisik terhadap aparat. Suatu kejadian dapat dikatakan apabila ada sekerumunan orang melakukan hal diluar prosedur untuk demonstrasi. Hal-hal yang sudah diatur seperti tidak boleh demonstrasi di hari minggu, demonstran harus tertib, dan lain-lain. Selain kontak fisik, ketika terjadi kontak senjata dengan menggunakan batu, bom molotov terhadap aparat gabungan itu juga disebut kerusuhan (Wawancara dengan Reza Ramadhan pada 30 Juni 2019)

Peliputan kerusuhan Aksi 22 Mei 2019 sedikit berbeda tapi maknanya sama. Banyak massa yang menjadi oknum kerusuhan atau ada orang yang disusupkan untuk kepentingan tertentu. Hal itu sudah direncanakan oleh perusuh untuk membuat kerusuhan di berbagai titik di Jakarta Pusat. Pernyataan ini juga sudah ditetapkan oleh pihak penyelidikan.

Cindy Permadi juga mengatakan bahwa kerusuhan Aksi 22 Mei 2019 itu kronologisnya berbeda dengan kejadian pada siangnya. Kegiatan yang dilakukan oleh massa aksi damai untuk menuntut Bawaslu agar independen dan adil mengenai hasil rekapitulasi pemilu. Tetapi saat menjelang malam ada massa yang berbeda menghampiri aparat dan tidak ada hubungannya dengan massa aksi damai. 
Pernyataan di atas didukung penjelasan lainnya, konflik yang berujung kerusuhan yang identik dengan tindakan kekerasan dikarenakan adanya perbedaan baik pendapat maupun keputusan. Selain itu, sumber atau faktor penyebabnya bermuara dari berbagai perbedaan, tata nilai, kepentingan dan pengakuan hak kepemilikan (Jamaludin, 2015: 40).

Seluruh informan memahami adanya konflik antar kubu atau kelompok sebagai penyebab adanya kerusuhan. wartawan televisi harus memahami terlebih dahulu mengenai kerusuhan Aksi 22 Mei 2019. kerusuhan yang tidak dapat diprediksi bisa terjadi kapan saja. biasanya disebabkan terjadinya kondisi hidup masyarakat yang tidak baik, adanya tindakan penindasan yang dilakukan pemerintah kepada rakyat, perselisihan agama atau etnis. Sehingga seorang wartawan juga harus bisa memahami kerusuhan Aksi 22 Mei 2019 dari segala aspek. Agar informasi yang disampaikan lewat audio visual tersebut dapat dimaknai secara jelas oleh khalayak umum.

Sesuai dengan hasil penelitian mengenai pemahaman sebagai wartawan televisi tentang peliputan kerusuhan Aksi 22 Mei 2019. Salah satu informan wartawan televisi Anan Suryana memahami etika peliputan kerusuhan. Etika dari segi pengambilan gambar tidak boleh mengambil gambar suatu tindakan-tindakan yang dapat memancing amarah. Wartawan harus membawa prinsip-prinsip damai. jika wartawan melihat adanya tindakan kekerasan sebisa mungin jangan diambil

Etika peliputan kerusuhan merupakan hal yang dilakukan wartawan saat di lapangan. Hal itu dipahami Adi Noval Saputra. Etika peliputan kerusuhan yang dilakukan wartawan yaitu selalu di belakang brimob untuk keamanan wartawan itu sendiri. selain itu, sebagai wartawan televisi harus membawa id card dan menggunakan seragam kerja.

"Untuk etika sebenarnya pasti diatur keras ya misalnya wartawan itu selalu ada di belakang brimob ya untuk keamanan jadi kita disediakan ruang liputan kita itu harus dibelakang brimob, memang liputan secara menyeluruh memang gak bisa semua wartawan di belakang brimob, sama pake id, seragam, itu untuk membedakan mana wartawan mana massa" (Wawancara pada 30 Juni 2019)

Hal serupa dijelaskan Cindy Permadi mengenai etika peliputan kerusuhan. Etikanya wartawan tidak boleh menjelaskan soal kekerasa terlalu detail karena hal itu tidak dibolehka. Ketika wartawan mengambil gambar kekerasan tidak sesuai kode etik jurnalistik dapat menimbulkan provokasi.

Etika peliputan kerusuhan itu tidak boleh menampilkan suatu tindakan kekerasan. Tindakan kekerasan seperti adanya korban berdarah-darah kemudian ada anak usia dibawah umur yang mengalami kekerasan itu. Pernyataan ini sesuai dengan penjelasan, bahwa wartawan Indonesia pantang menyiarkan karya jurnalistik (tulisan, suara, serta suara dan gambar) yang menyesatkan memutar balik fakta, bersifat fitnah, cabul serta sensasional (PWI, 2007).

Seluruh informan mengungkapkan etika peliputan kerusuhan tidak boleh menjelaskan gambar sedetail mungkin. Jika ada tindakan-tindakan kekerasan diusahakan wartawan tidak mengambil gambar ersebut. Hal itu dikarenakan untuk menjaga perasaan masyarakat dan kemungkinan dapat menimbulkan emosional. Sebagai pencari berita, wartawan juga harus netral tidak boleh berpihak pada salah satu kubu yang akan menimbulkan provokasi. 
Dalam kondisi apapun wartawan televisi harus menerapkan peraturan keselamatan yang menjadi hal utama saat peliputan. Sebagai pencari informasi yang akan disebarluaskan kepada publik, wartawan televisi harus pandai menempatkan posisi saat peliputan kerusuhan berlangsung. Sebelum menentukan posisi seorang wartawan televisi harus melakukan pendekatan kepada aparat atau pun massa aksi. Melalui pendekatan, kita akan mengetahui bagaimana kondisinya dan untuk melakukan pengambilan gambar akan aman dan memudahkan dalam peliputan. Untuk jarak antara wartawan dengan lokasi keusuhan seberaninya saja dan tetap harus menjaga alat agar tidak terjadi kerusakan. Hal itu diungkapkan oleh Laras Kiranasari.

Posisi wartawan televisi tidak jauh dari petugas. Hal itu dikarenakan untuk keselamatan wartawan sendiri. ketika kerusuhan terjadi wartawan pun mendekat ke aparat. Jarak dari aparat ke wartawan itu 5 meter sedangkan jarak wartawan dengan titik kerusuhan sekitar 100 meter (Wawancara pada 8 Juli 2019)

Cindy Permadi juga menyampaikan hal yang sama degan Rahajeng Mutiara bahwa posisi wartawan televisi harus berada di posisi yang dapat memberikan gambar terbaik untuk disebarluaskan. Posisi wartawan yang paling baik dan benar itu di belakang polisi, hal itu dikarenakan tidak semua massa aksi ingin diliput oleh wartawan televisi. Meskipun berada dibelakang polisi wartawan harus tetap mengambil gambar yang jelas untuk menjelaskan situasi yang sedang terjadi dilapangan. Hal ini sejalan dengan pernyataan Solihin yaitu Proses peliputan peristiwa kerusuhan tergantung pada persiapan yang dilakukan dan bagaimana seorang wartawan foto ketika di lapangan dalam menentukan posisi (Solihin, 2018: 67).

Dari pembahasan tersebut seluruh informan memahami posisi saat liputan atau live report harus menempatkan diri pada posisi yang aman. Hal itu dikarenakan untuk kepentingan keselamatan wartawan. Posisi wartawan yang aman saat peliputan kerusuhan yaitu berada di sekitar aparat. Jika wartawan melakukan liputan dengan baik dan lancar, berita yang akan disebarluaskan pun akan maksimal dan kerusuhan Aksi 22 Mei 2019 dapat menarik perhatian penonton

Pemaknaan Wartawan Televisi Mengenai Peliputan Kerusuhan Aksi 22 Mei 2019. Makna terhadap sebuah realitas dalam teori fenomenologi ini bukan hanya makna yang berasal dari individu sendiri, namun juga bersifat intersubjektif (Kuswarno, 2009: 110).

Camera person memaknakan bahwa peran wartawan televisi saat peliputan kerusuhan sangat penting karena wartawan televisi berada di lapangan untuk memberitakan kepada masyarakat. Hal itu dikarenakan jika bukan wartawan yang memberikan informasi maka tidak ada yang bisa menggantikan posisi wartawan sebagai pencari berita. Informasi yang disebarluaskan juga bersifat netral, tidak ada di salah satu pihak tapi dibeberapa titik (Wawancara pada 8 Juli 2019).

Peran wartawan televisi saat peliputan kerusuhan memaknai bahwa peran wartawan televisi memiliki peran tersendiri yaitu dapat menjelaskan informasi dengan menyajikan gambar dan suara. Dengan gambar masyarakat akan melihat kondisi lapangan secara langsung. Jika wartawan mengambil gambar situasi yang kuat, maka reporter tidak perlu banyak berbicara untuk menjelaskan kondisi lapangan karena sudah diwakili oleh gambar. 
Hal serupa disampaikan oleh Anan Suryana bahwa pada media televisi selain membuat laporan yang diucapkan oleh reporter wartawan televisi juga memiliki gambar untuk menjelaskan kondisi yang terjadi di lapangan. Jika semua sudah terekam kamera oleh wartawan televisi, hal itu tidak bisa dibantah bahwa itu benarbenar terjadi. Sebagian masyarakat ada yang mengatakan hoax, meskipun ada foto dan video yang bisa dinarasikan, hanya dengan adanya gambar dapat memperkuat informasi yang wartawan sampaikan untuk masyarakat (Wawancara pada 26 Juni 2019). Beberapa tugas wartawan yang patut menjadi perhatian dalam menjalankan tugas yaitu menyajikan fakta, menafsirkan fakta, dan mempromosikan fakta (Bennet dalam Yunus, 2012: 40).

Peran wartawan televisi saat peliputan kerusuhan sangat penting karena wartawan televisi berada di lapangan untuk memberitakan kepada masyarakat. Hal itu dikarenakan jika bukan wartawan yang memberikan informasi maka tidak ada yang bisa menggantikan posisi wartawan sebagai pencari berita. Informasi yang disebarluaskan juga bersifat netral, tidak ada di salah satu pihak tapi dibeberapa titik.

Seluruh informan mengungkapkan peran wartawan televisi pada peliputan kerusuhan sangatlah penting. Hal itu dikarenakan wartawan televisi menyajikan berita secara audio visual. Hal itu supaya masyarakat mengetahui secara jelas kronologi kejadian dan fakta-fakta di lapangan lainnya.

Peliputan kerusuhan identik dengan adanya konflik antar kelompok dan kekerasan, baik itu fisik atau non fisik. Tidak menutup kemungkinan pada peristiwa kerusuhan biasanya terdapat adanya korban. Wartawan sebagai orang yang ada di lokasi kerusuhan pasti dihadapkan dengan melihatnya korban kerusuhan. Hal ini akan membuat wartawan melakukan tindakan, mendahulukan humanisme atau profesionalisme.

Menurut Kamus Besar Bahasa Indonesia Humanisme adalah aliran yang bertujuan menghidupkan rasa perikemanusiaan dan mencita-citakan pergaulan hidup yang baik (Kamus Besar Bahasa Indonesia Onlline, 2016). Peliputan kerusuhan yang utama itu humanisme. Tetapi ketika pelliputan kerusuhan Aksi 22 Mei 2019 Anann Suryana mengalami masalah, korban yang berjatuhan tidak jelas identitasnya apakah masyarakat yang baik atau masyarakat yang menjadi oknum kerusuhan.

Peliputan kerusuhan wartawan mendahulukan humanisme jika dihadapkan dengan melihat korban kerusuhan. Setelah humanisme wartawan akan bersikap profesionalisme sebagai pencari berita. Hal itu terjadi karena wartawan juga manusia dan akan membantu wartawan lainnya yang menjadi korban kerusuhan. Selain membntu sesama manusia, wartawan juga harus memperhatikan keselamatan diri sendiri (Wawancara pada 30 Juni 2019).

Pada saat peliputan kerusuhan Aksi 22 Mei 2019 dihadapkan dengan melihat massa yang menjadi korban tapi akrena ada polisi jadi dia menyerahkan ke pihak yang berwenang. Selain itu, Nadia Raissa juga dihadapkan momentum adanya korban yang menimpa wartawan. Hal itu terjadi karena wartawan ini tertimpuk batu sehingga mengalami bocornya kepala. Meskipun posisi Nadia Raissa sedang berlarilari menyelamatkan diri tapi dia melakukan tindakan yaitu menawarkan odol untuk perlindungan mata.

Pada peliputan kerusuhan yang utama itu humanise jika dihadapkan dengan melihat korban kerusuhan. Setelah humanisme wartawan akan bersikap profesionalisme sebagai pencari berita. Hal itu terjadi karena wartawan juga manusia 
dan akan membantu wartawan lainnya yang menjadi korban kerusuhan. Selain membntu sesama manusia, wartawan juga harus memperhatikan keselamatan diri sendiri.

Peliputan kerusuhan Aksi 22 Mei 2019 dihadapkan dengan melihat massa yang menjadi korban tapi karena ada polisi jadi dia menyerahkan ke pihak yang berwenang. Informan juga dihadapkan momentum adanya korban yang menimpa wartawan. Hal itu terjadi karena wartawan tertimpuk batu sehingga mengalami bocornya kepala.

Seluruh informan dalam penelitian memilih untuk mendahulukan humanisme dibandingkan profesionalisme jika dihadapkan dengan melihat adanya korban kerusuhan. Korban kerusuhan tidak hanya dialalmi oleh masyarakat saja tetapi wartawan juga bisa jadi korban kerusuhan. Hal ini dilakukan karena wartawan juga manusia yang memiliki hti nurani untuk merasakan apa yang sedang dialami korban. Apalagi jika korban adalah rekan wartawan, sesama pencari berita juga tetap adanya rasa solidaritas.

Pengalaman Wartawan Televisi pada Peliputan Kerusuhan Aksi 22 Mei 2019. Fenomena bukanlah dirinya secara kasat mata, melainkan justru ada di depan kesadaran, dan disajikan dengan kesadaran pula (Kuswarno, 2009: 1) Pengalaman wartawan televisi saat melakukan peliputan kerusuhan Aksi 22 Mei 2019 sangatlah beragam. Berkaitan denga hal ini, maka fenomenologi merefleksikan pengalaman langsung manusia, sejauh pengalaman itu secara intensif berhubungan dengan suatu objek. Terkait dengan pernyataan Kuswarno di atas, peneliti ingin mengetahui pengalaman wartawan televisi sebagai objek yang melakukan kegiatan yaitu pengalaman peliputan kerusuhan Aksi 22 Mei 2019. Sebagai wartawan televisi diperkirakan ketujuh informan yang menjawa wartawan televisi di Jakarta pernah bahkan sering meliput kerusuhan sehingga dapat dikatakan memiliki pengalaman berkaitan peliputan kerusuhan Aksi 22 Mei 2019. Hal tersebut akan mengetahui ketika situasi kondisi saat berlangsungnya kerusuhan Aksi 22 Mei 2019.

Berdasarkan hasil temuan di lapangan, peneliti membagi kedalam tiga aspek yaitu, hambatan peliputan, adanya intimidasi dan diskriminasi, serta keselamatan peliputan. Sehingga dengan adanya hal tersebut peneliti akan mengetahui pengalaman wartawn televisi dari informasi yang didapat saat melakukan wawancara.

Wartawan televisi dalam penelitian ini mengaku hambatan peliputan datang dari persoalan teknis dan nonteknis. Hambatan teknis misalnya ditemukan saat akan live report. Seperti yang dialami salah satu informan menjelaskan tentang pengalamannya saat proses peliputan kerusuhan Aksi 22 Mei 2019. Saat proses peliputan mengalami hambatan yang cukup berpengaruh terhadap peliputan. Hambatannya yaitu dikarenakan wartawan televisi saat proses peliputan membutuhkan sinyal yang kuat untuk live report ternyata sinyalnya di jump atau di block. Sehingga wartawan televisi mengalami gangguan, tetapi hanya wartawan televisi yang memiliki satelit tambahan saja yang bisa live report.

Hambatan saat peliputan kerusuhan Aksi 22 Mei 2019 yaitu ketika pihak aparat akan melakukan tindakan-tindakan diluar SOP wartawan televisi harus menutup kamera agar tidak terekam. Hal itu bukannya wartawan ingin menjaga citra aparat tetapi agar tidak menimbulkan situasi yang membuat amarah penonton. Selain itu ada hambatan teknisya yaitu adanya miss komunikasi sehingga adanya keterbatasan. Sinyal tidak terlalu baik untuk koordinasi dengan pihak kantor. 
Sehingga hanya mengandalkan tim dan juga wartawan-wartawan dari media lain yang pada akhirnya jadi satu tim. Meskipun menjadi satu tim tapi tetap informasi yang disajian unrk media wartawannya masing-masing

Hambatan proses peliputan kerusuhan Aksi 22 Mei 2019 adalah, sinyal di sekitar lokasi peliputan tepatnya sekitar bawaslu maupun di Jakarta Pusat itu di jumping atau block. Posisi wartawan televisi harus live report dan Adi Noval Saputra menggunakan alat the zero tapi ketika sinyalnya di block wartawan televisi tidak bisa melakukan live report. Selain itu, wartawan juga tidak bisa menggunakan WhatsApp atau pun telpon. Jadi sinyal saat itu tidak bisa naik, yang bisa naik hanya wartawan yang memiliki mobil besar SNG. Karena sinyal yang menjadi hambatan peliputan sehingga terjadinya gagal live report berkali-kali.

Hambatan yang dijelaskan diatas memiliki hubungan dengan tidak tergaanngu jalannya alat komunikasi. pernyataan tersebut berkorelasi dengan pentingnya media massa untuk menjadi alat komunikasi. media massa atau alat komunikasi merupakan alat bantu yang berperan penting dalam proses sebuah komunikasi. secara sederhana proses komunikasi yang didukung oleh media sangat efektif untuk mentransformasikan informasi ke khalayak ramai dalam jangauan yang luas (Sabari, 2017: 78).

Dengan demikian, profesi wartawan televisi itu bukan pekerjaan yang mudah untuk digeluti. Selain menguras pengetahuan dan kemampuan, wartawan televisi harus melakukan berbagai persiapan yang dibutuhkan untuk keamanan dan kenyamanan dalam proses peliputan.

Reza ramadhan mengungkapkan bahwa dia mengalami tindakan tekanan secara verbal oleh masyarakat. Hal itu dikarenakan bahwa masyarakat sudah tidak percaya kepada media di Indonesia. Bukti ketidakpercayaan itu dapat dirasakan oleh Reza Ramadhan karena masyarakat mengatakan hal yang menjelaskan bahwa CNN Indonesia tidak pernah memberitakan hal yang benar. Selain itu, pengambilan gambar oleh wartawan juga dipertanyakan oleh masyarakat, ketika wartawan mengambil gambar sesuai kondisi lapangan dan di lokasi itu ada masyarakat, masyarakat pun meragukan ke profesionalan wartawan apakah gambarnya akan ditayangkan atau tidak.

Dampak yang dialaminya dilakukan oleh massa yang menghalangi saat live report. Massa tidak tahu apayng diberitakan oleh wartawan televisi dan mnganggap bahwa wartawan televisi itu tidak benar dalam memberitakan dengan mengatakan hoax. Hal itu kemungkinan masyarakat tidak mau diliput atau diberitakan sehingga mereka melakukan itu (Wawancara pada 8 Juli 2019)

Definisi kekerasan terhadap wartawan dalam Dewan Pers yang dimaksud ialah kekerasan terhadap wartawan yang sedang menjalankan pekerjaan jurnalistik atau kekerasan yang diakibatkan oleh karya jurnalistiknya, bentuk kekerasan yang dimaksud adalah; penganiayaan ringan, penganiayaan berat, penyiksaan, penyekapan, penculikan dan pembunuhan, kekerasan non fisik diantaranya, penghinaan, penggunaan kata-kata yang melecehkan, perusakan peralatan liputan, upaya menghalangi kerja wartawan untuk mencari, memperoleh, memiliki, menyimpan, mengolah, dan menyampaikan informasi, atau tindakan apa pun yang menghalangi tugas wartawan.

Berdasarkan hasil penelitian tidak semua wartawan mengalami tindakan intimidasi. Wartawan yang mengalami hal itu terjadi dalam bentuk verbal maupun 
non verbal. Baik fisik maupun non fisik yang dilakukan oleh massa atau aparat. Keselamatan wartawan dalam peliputan kerusuhan, wartawan mendapatkan asuransi dari medianya sendiri. tetapi hal yang paling penting untuk selalu menjaga keselamatan wartawan adalah dirinya sendiri. ketika Anan Suryana meliput konflik di Papua, Anan Suryana iminta untuk menandatangani perjanjian mengenai jaminan keselamatan. Sebagai wartawan hanya bisa berikhtiar seperti jangan melakukan tindakan-tindakan bodoh. Maka dari itu riset, terus apa saja yang kita butuhkan saat di lapangan, siapa yang akan memberikan bantuan ketika kita kesulitan di lapangan, itu sangat penting.

Hal serupa dikatakan oleh Reza Ramadhan bahwa kantor menjamin keselamatan wartawannya. Hal itu dapat dilihat dari sebelum liputan, wartawan dibekali peralatan keselamatan. Melihat kasus yang pernah terjadi, ada jaminan yang diberikan media yaitu jaminan kesehatan ketika terjadi kecelakaan kerja. Selain itu, pihak media juga akan melakukan pendampingan hukum untuk menyelesaikan kasusnya yang menimpa wartawan. Jaminan keselamatan wartawan saat peliputan kerusuhan Aksi 22 Mei 2019 jaminannya berbentuk dukungan. Jika ada wartawan yang mengalami kecelakaan kerja maka ada asuransi dari kantor. Selain memberikan asuransi, pihak media pun melindungi wartawannya dengan proses hukum. Perusahaan pers wajib menyediakan peralatan dan keahlian keselamatan untuk para wartawannya. sementara wartawan membutuhkan kesadaran untuk mematuhi standar keselamatan yang telah ditetapkan oleh perusahaannya maupun pihak lain (Dewan Pers)

Keselamatan peliputan untuk seorang wartawan televisi adalah suaru hal yang penting untuk menjalankan tugasnya yaitu meliput kerusuhan Aksi 22 Mei 2019. Salah satunya saat melakukan peliputan khusus yang berkaitan dengan kerusuhan. Kantor juga harus menjamin keselamatan untuk wartawannya dan pembekalan pengetahuan tentang cara peliputan kerusuhan Aksi 22 Mei 2019.

\section{KESIMPULAN}

Pemaknaan peliputan kerusuhan Aksi 22 Mei 2019 terdapat dua aspek peran wartawan televisi dan mendahulukan humanisme. Seluruh informan menyepakati bahwa peran wartawan televisi pada peliputan kerusuhan sangatlah penting karena menyajikan berita secara audio visual supaya masyarakat mengetahui secara jelas kronologi kejadian dan fakta-fakta di lapangan lainnya. Seluruh informan memilih untuk mendahulukan humanisme dibandingkan profesionalisme jika dihadapkan dengan melihat adanya korban kerusuhan.

Pada penelitian ini pengalaman peliputan kerusuhan Aksi 22 Mei 2019 terbagi menjadi tiga aspek yaitu, hambatan peliputan profesi wartawan televisi itu harus melakukan berbagai persiapan yang dibutuhkan untuk keamanan dan kenyamanan dalam proses peliputan. Tidak semua wartawan mengalami tindakan intimidasi. Wartawan yang mengalami hal itu terjadi dalam bentuk verbal maupun non verbal yang dilakukan oleh massa atau aparat. Keselamatan peliputan, tidak semua wartawan diberikan pembekalan alat keselamatan oleh medianya dan tidak semua wartawan mendapatkan asuransi atau jaminan keselamatan dari media. 


\section{DAFTAR PUSTAKA}

Darsono, D., \& Muhaemin, E. (2012). Peristiwa di Mata Wartawan. Mimbar Pustaka.

Dirgahayu, D. (2018). Persepsi Wartawan Terhadap Aktivitas Jurnalistik In-vestigasi. Jurnal Penelitian Komunikasi, 18(1), 79-88.

Jamaludin, A. N. (2015). Agama \& Konflik Sosial. Bandung: Pustaka Setia. Pustaka Setia.

Kamus Besar Bahasa Indonesia Onlline. (2016). Kamus Besar Bahasa Indonesia (KBBI) onlline.

Kuswarno, E. (2009). Metode Penelitian Komunikasi: Fenomenologi. Widya Padjajaran.

Mardira, S. (2019). AJI: 20 Wartawan Jadi Korban Kekerasan Aksi 22 Mei, Terburuk Sejak Reformasi. https://www.google.com/amp/s/news.okezone.com

Morissan. (2009). Manajemen Penyiaran (Strategi Mengelola Radio \& Televisi). Kencana Prenada Media Group.

Muchtar, K., \& Ghalia, F. R. (2018). Respon Mahasiswa terhadap Tayangan Dakwah Islamiyah Khazanah (Trans 7) dan Damai Indonesiaku (Tv One). INJECT (Interdisciplinary Journal of Communication), 3(2), 147-174.

Nusyur, R. (2017). Jurnalisme Damai Dalam Pemberitaan Pembakaran Ger-eja di Aceh Singkil Pada Harian Waspada. Jurnal Komunikasi Global, 6(1).

Purnama, F. (2019). Pemikiran Parni Hadi Tentang Jurnalisme. Communicatus: Jurnal Ilmu Komunikasi, 3(1), 35-52.

PWI. (2007). Kode Etik Jurnalistik (Kej) Persatuan Wartawan Indonesia (PWI). https://pwi.or.id/

Sabari. (2017). Manajemen Media Massa Hizbut Tahrir Indonesia. Ilmu Dakwah: Academic Journal for Homiletic Studies, 11(1), 73-88.

Shasrini, T. \&, Daherman, \& Daherman, Y. (2018). Aktivisme Cyber Army di Media Sosial (Studi Fenomenologi Komunitas Unit Kegiatan Mahasiswa Islam di Universitas Islam Riau). Medium, 6(2), 61-67.

Solihin, A. (2018). Pandangan Wartawan Foto Bandung (WFB) tentang Pen-galaman Peliputan Perstiwa Kerusuhan. Jurnal Ilmu Jurnalistik, 3(4), 57-76.

Sukmono, Filosa Gita \& Junaedi, F. (2018). Jurnalisme Sensitif Bencana dalam Manajemen Pencarian, Pengelolaan Informasi dan Pemberitaan Bencana di Ruang Redaksi. Jurnal ASPIKOM, 3(4), 712-721. https://doi.org/http://dx.doi.org/10.24329/aspikom.v3i4.185

Sulaeman. (2015). Studi Profesionalisme Melalui Pengalaman Komunikasi Jurnalis Perempuan Di Media Masssa Kota Ambon. Jurnal Fikratuna, 7(2).

Syahputra, I. (2013). Rezim Media: Pergulatan Demokrasi, Jurnalisme, Info-tainment dalam Industri Televisi.

Yunus, S. (2012). Jurnalistik Terapan. Ghalia Indonesia. 